\title{
武汉后湖浮游植物现存量与生产量 季节变动的初步研究
}

\author{
我 克 文 \\ (中国科学院水生生物研究所,武汉 430072)
}

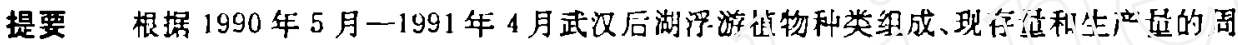

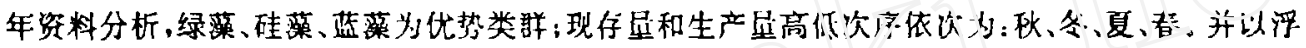

游植物群落生态作为主要依据对后湖的营养状态进行了综会评倠，

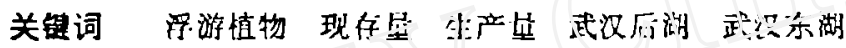

后湖原是凉湖的一个湖湾, 60 年代 筑堤分隔浅独立子湖, 北部与牛巢湖虽 有土堤相隔, 但有一铁楖栏闸门相通。后 湖三面环山, 一边为农田, 周围村生稀 少。环湖陆生植被以果树、松树、灌木林 及杂草为主。湖湾区有一个集体渔场附 属小型奶牛场, 饲养奶牛仅 4 头。作为鱼 塘肥源。少量生活污水不直接排入湖湾 亦通过农田、果园利用吸收后随地表适 流排入。湖区面积年平均约为 $467 \mathrm{hm}^{2}$ 。 最大水深丰水期时约为 $3.5 \mathrm{~m}$, 枯水期时 约为 $2.5 \mathrm{~m}$ 。透朋度年变动范用在 $0.5-$ $1.30 \mathrm{~m}$ 之问。该湖沿朔带水生高等植物 生长茂密。植被覆盖面约占全湖 $25 \%$, 年 平均生物量为 $718.13 \mathrm{~g} / \mathrm{m}^{3}$ 。主要种群为

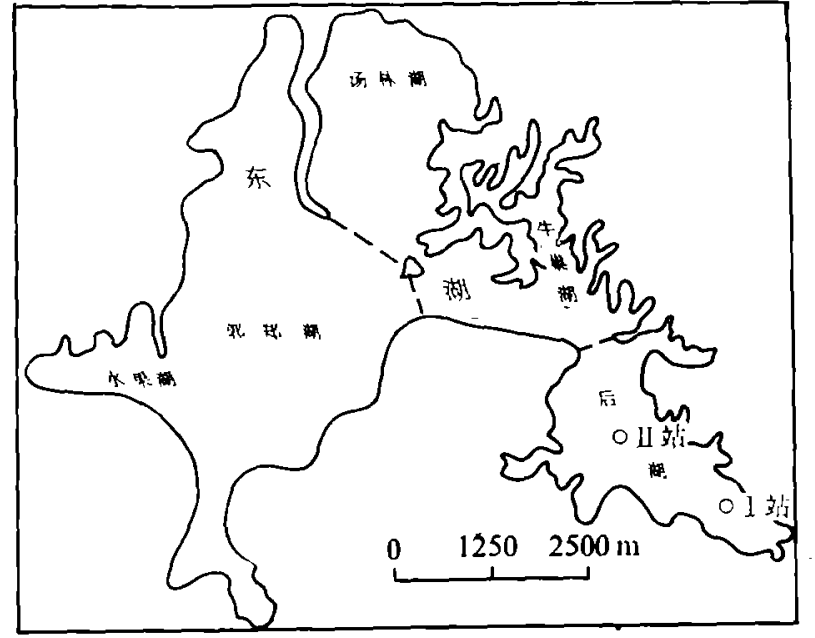

终 1 武汉后湖采样站及位置图

Fig. 1 Locations of Hubu Lakc and sampling stations 聚草、苦草、莲、野菱等，与东湖，其它湖区相比，该湖的天然水生植物最为本富。

为了解该湖区浮游植物的种群组成、现存望和生产量的季节变动,设两个采样站: I 站 位于东南湖汊; I站位于湖区中心(图 1), 逐月你层(离水面 $0.5 \mathrm{~m}$ 及距湖底 $0.5 \mathrm{~m}$ ) 果样一 次。同时对水温、透吸度、氮、磷等水的理化因子进行了观测。

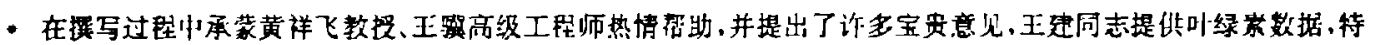
此一并致谢。

收腹日期: 1992年9月28日：接受日期: 1993年 3 月 20 日。
} 


\section{1 工作方法}

\section{1 样品的采集和处理}

游植物定性、定望样品的果集和处理按常规方法进行 ${ }^{[1]}$ 。

\section{2 叶绿害含量的测定}

用尔水器采上、下层水混匀后, 取 $2.5 \mathrm{~L}$ 带回室内。根据水中落类多赛取出适量水样,经 Whatman GF/C 微孔滤膜抽誌。用 $90 \%$ 乙醇作为溶剂，在低温黑暗条件下抽提 $24 \mathrm{~h}$ 再用 722 型分光光度计测定酸化前后光密度,测定波长分别为 $665.750 \mathrm{m \mu}$ 。最辰用 $\mathrm{i}$. crenzon 公 式计算其叶绿素含量。

\section{3 浮游植物初级生产量的测定 ${ }^{[2}$}

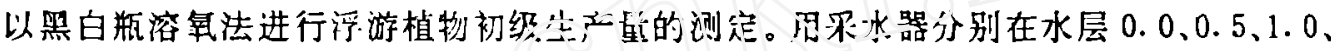

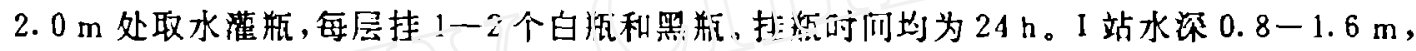
挂瓶 3 层; I 站水深 $2.5-30 \mathrm{~m}$, 挂酒 $\mathrm{i}$ 层。乐用温完勒法测定曝光前后溶解氧变化。

\section{2 结果与讨论}

\section{1 浮游植物种类组成}

经初步鉴定,后湖浮游植物约 60 种,承属于 7 门 53 属(表 1)。全年大多数月份以绿落 门的种类数最多,达 28 种; 硅䔀门种类数次之,为 15 种; 蓝藻门再次之, 只有 9 种; 其他各门 种类较少,一般仅有 2-3 种。因此,后湖藻类群落为“绿落十硅藻十蓝藻”型。

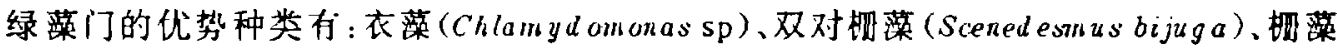
(Scened smus sp)、小球㩰 (Chlorella vulgaris)，湖生卵藻 (Oacysis lacustis)、小形月牙藻 (Selenastumminutum)。硅藻门的代势种类有：梅尼小环藻 (Cyclotella Menegliniana)，颗粒 直链藻 (Melosira Granulala)、园形舟形落 (Navichual Placenlul)、菱形 (Nilzschus $\mathrm{sp}$ )、脆杆

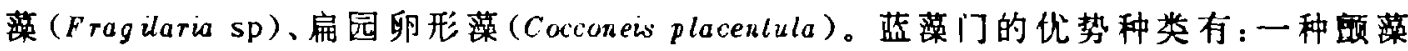

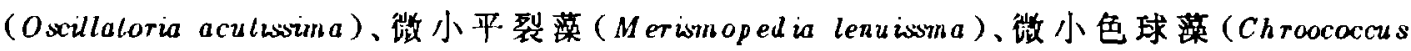

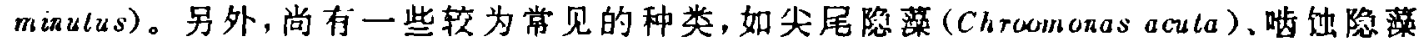

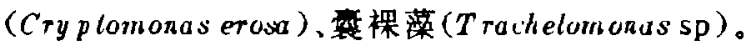

\section{2 浮游植物数量和生物量的季节变动}

2.2.1 数量变动 后湖 I 站浮游植物数量,全年波动在 11950-108980个 $/ \mathrm{mL}$ 之问。生物 量波动在 $2.095-11.572 \mathrm{mg} / \mathrm{L}$ 之问。I 站浮游植物数望, 全年波动在 $56820-$ 203280 个 $/ \mathrm{mL}$ 之问(图 2)。

I站浮游植物数重以秋季最高 $(203280$ 个 $/ \mathrm{mL})$, 冬季次之 $(189780$ 个 $/ \mathrm{mL})$, 夏季再次 之 $(91600$ 个 $/ \mathrm{mL})$, 春季最低 $(69560$ 个 $/ \mathrm{mL})$ 。I 站浮游植物数量季节分布规律与 I 站相似, 即秋季最高 $(108980$ 个 $/ \mathrm{mL})$, 冬季次之 $(83320$ 个 $/ \mathrm{mL})$, 夏季和春季的浮游植物数量咯低, 仯别为 75400 及 73280 个 $/ \mathrm{mL}$ (表 2 )。 
表 1 武汉后湖浮游植物种类组成

Tab. 1 Specie composition of phytoplankton in Houhu Lake, Wuhan

\begin{tabular}{|c|c|c|c|c|}
\hline 种 & 者 & $z$ & 欧 & 冬 \\
\hline \multicolumn{5}{|l|}{ 绿薄门 Chlopte } \\
\hline 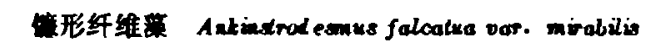 & ++ & + & ++ & + \\
\hline 衣藻 Chlamydomanas sp & +++ & +++ & +++ & ++ \\
\hline 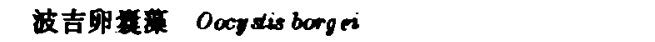 & + & ++ & ++ & + \\
\hline 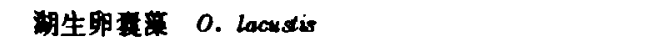 & ++ & ++ & ++ & ++ \\
\hline 浮球営 Plaxktasphaeria sp & & + & + & + \\
\hline 四角十字㩰 Crucigenia quad rala & & + & + & + \\
\hline 四足十字豏 $c$. leraped in & + & & & \\
\hline 美丽胶网蓝 Dictyasphaerium pulchellum & & $\dashv$ & + & \\
\hline 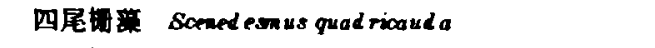 & & + & + & \\
\hline 二形期暴 S. dimorphus & & + & & \\
\hline 双对相湿 S. bijega & i & ++ & -+ & ++ \\
\hline 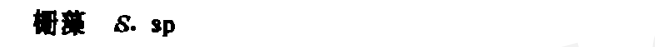 & $t-+\cdot t$ & $+\div$ & $++t$ & +++ \\
\hline 单独四星湿 Tetrastrum hastiferum & & + & & \\
\hline 新月烡 Claserium sp & + & + & & \\
\hline 小空星 Coelostrikm mixnormim & & + & & \\
\hline 四刺 7 rexbaina sp & & & + & \\
\hline 集星 Actavailou mantzscha & & + & & \\
\hline 木形月牙的i seienastrum mimutum & ++ & ++ & ++ & ++ \\
\hline 数小四角熦 Tetraedrom mininum & + & + & + & + \\
\hline 十字柱形站菻 Peninm cruciferum & & & & + \\
\hline 小球 Chlonella vulgaris & ++ & +++ & $++t$ & ++ \\
\hline 盘星赏 Ped indrum aruciserum & & + & + & \\
\hline 相肾形意 Nephrocytimm obesum & + & & & \\
\hline 线形投青斯落 Westellop sis linearis & + & & & \\
\hline 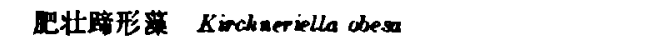 & + & & & + \\
\hline 硫刺多芒莫 Oolentinia pascispina & + & & & + \\
\hline 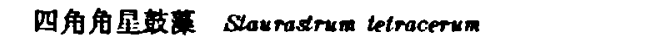 & & & + & \\
\hline 㩽落 Cusmarium sp & + & + & + & + \\
\hline \multicolumn{5}{|l|}{ 蓝策门 Cyanophta } \\
\hline 针状兰纤经湿 Dactylocacoop sis acicklaria & & & + & \\
\hline 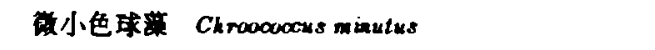 & ++ & ++ & ++ & ++ \\
\hline 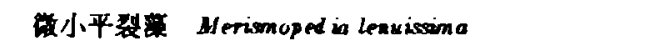 & + & + & + & + \\
\hline 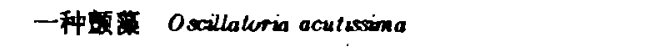 & ++ & ++ & ++ & +++ \\
\hline 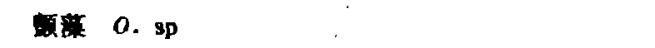 & & + & & \\
\hline 管抱菜 Chamaediphom sp & & & + & \\
\hline 粘杆黨 Gloecthece sp & & + & + & + \\
\hline 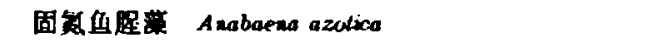 & & + & + & + \\
\hline 中华尖头薄 Raphid op sis sinensin & & + & + & \\
\hline \multicolumn{5}{|l|}{ Cryptophyta } \\
\hline 尖尾蓝隐萣 Chroumenas acula & ++ & + & $+t$ & $+t$ \\
\hline 唗蚛隐藻 Cryplomonas eraso & ++ & ++ & ++ & ++ \\
\hline \multicolumn{5}{|l|}{ 甲菒门 Pyrrophyta } \\
\hline 角甲営 Ceratium hirund inella & & & + & \\
\hline 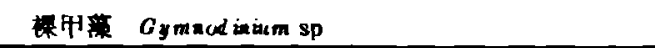 & & + & + & + \\
\hline
\end{tabular}




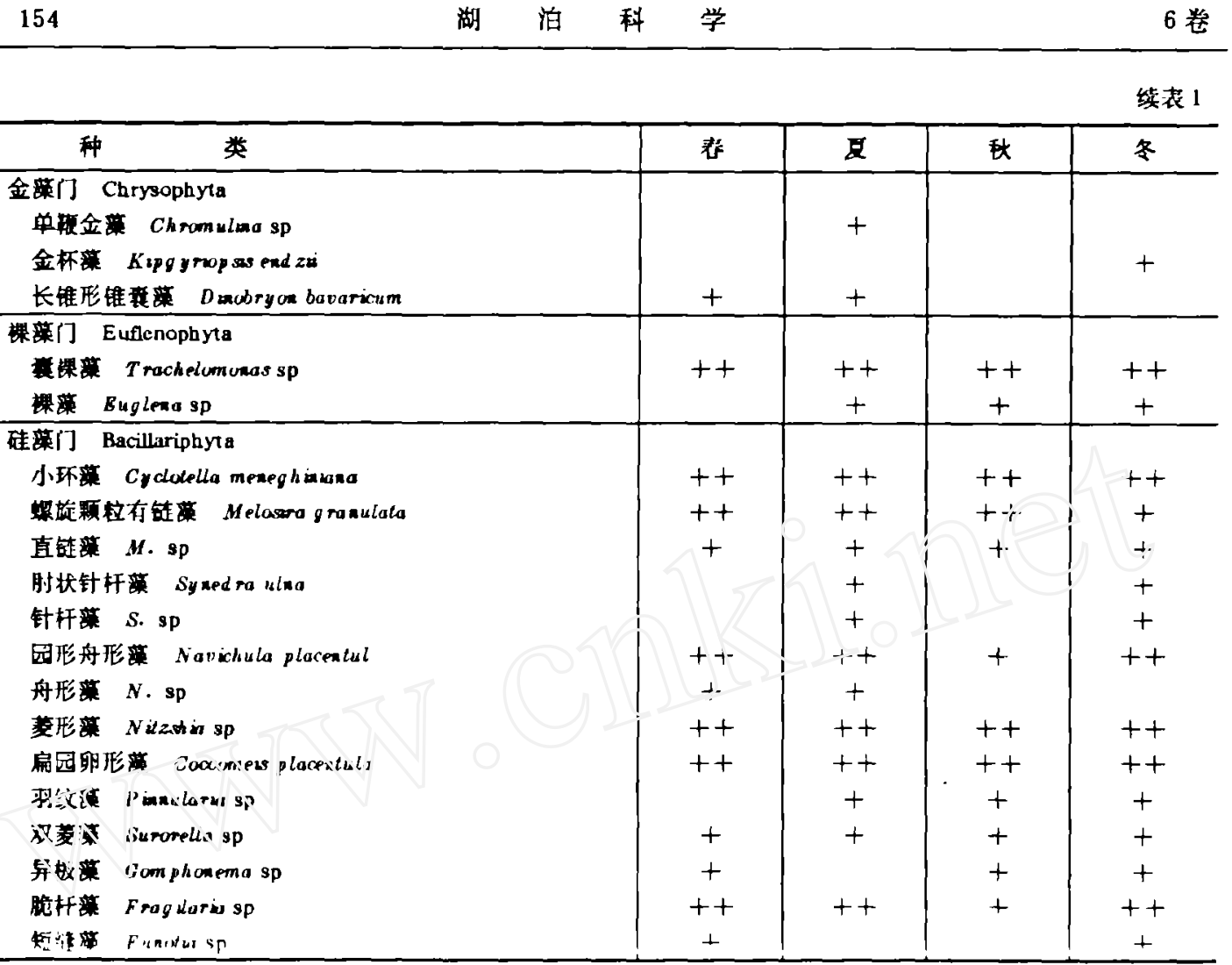

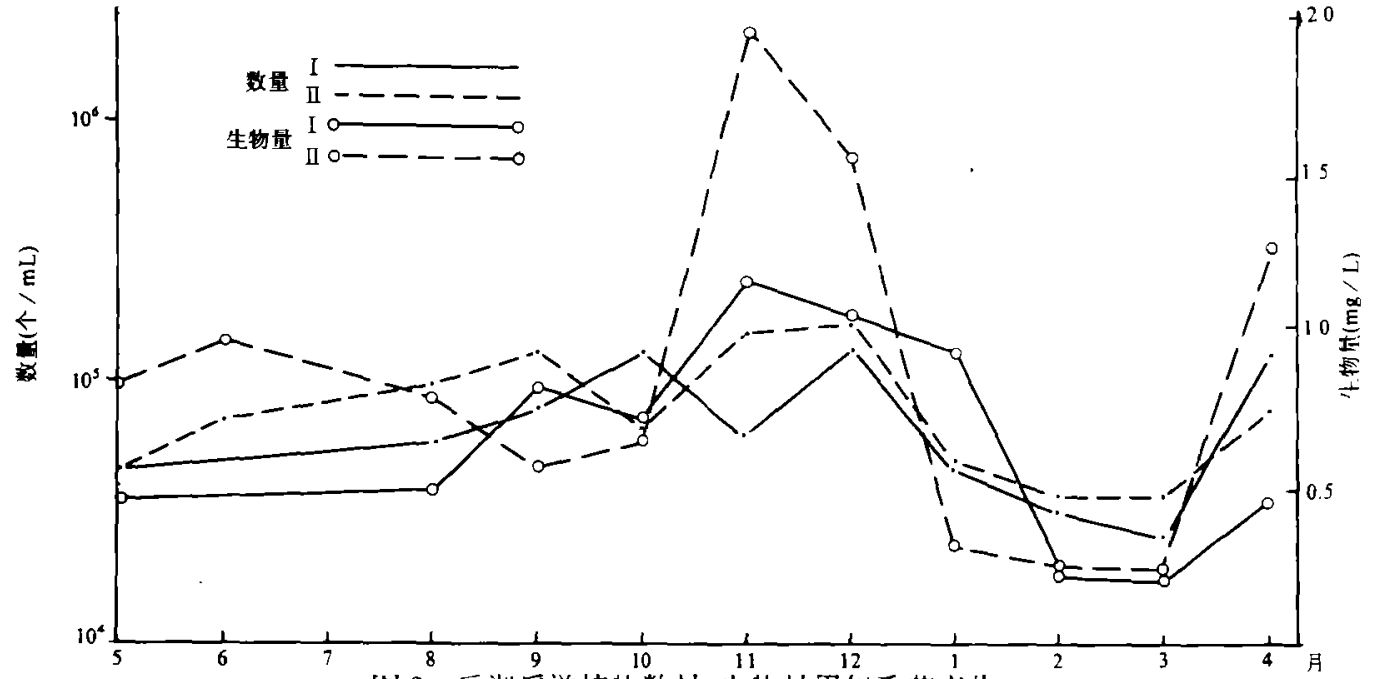

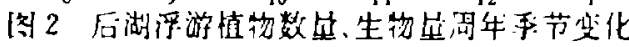

Fig. 2 Murrthiy varialiun of numbers and bjumass of pbstuplanklun an Huuhu Lake

后湖各门浮游植物数鱼和生物量在不同季节所占比例不同。从图 3、表 3 中可以看出,

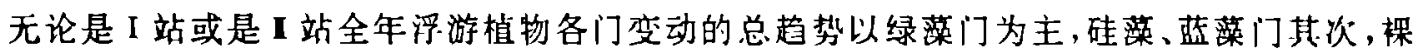

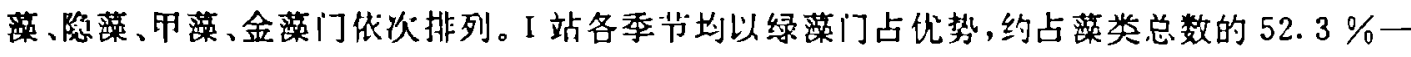
$59.4 \%$ 。I站浮游植物数量春、夏两季仍以绿落门为主，分别占落类总数的 $65.1 \%$ 和 
$51.0 \%$ 。秋、冬两季则以蓝藻的数量居多,分别高达 115930 个 $/ \mathrm{mL}$ 和 105400 个 $/ \mathrm{mL}$ 。占

表 2 后湖湖区浮斿植物数是与生物昷的乎节变动。

Tab. 2 Seasonal changes of density and biomass of various phytoplankton on Houhu Lake

\begin{tabular}{|c|c|c|c|c|c|c|c|c|c|c|}
\hline \multirow{2}{*}{ 种 类 } & \multicolumn{2}{|c|}{ 毒(3-5月) } & \multicolumn{2}{|c|}{$\overline{8}(6-8$ 月) } & \multicolumn{2}{|c|}{ 秋 $(9-11$ 月) } & \multicolumn{2}{|c|}{ 冬(12-2月) } & \multicolumn{2}{|c|}{ 年平均 } \\
\hline & 1 站 & 1 站 & 1 站 & I 站 & 1 站 & I 站 & I站 & I 站 & I 站 & 1 站 \\
\hline 绿灌门 & $\frac{43.54}{1.401}$ & $\frac{45.31}{5.810}$ & $\frac{40.89}{1.597}$ & $\frac{46.73}{5.568}$ & $\frac{59.16}{3.751}$ & $\frac{58.37}{5.636}$ & $\frac{43.63}{3.197}$ & $\frac{65.53}{4.353}$ & $\frac{46.81}{2.487}$ & $\frac{53.99}{5.342}$ \\
\hline 硅覇门 & $\frac{6.55}{0.574}$ & $\frac{7.08}{0.744}$ & $\frac{9.56}{0.715}$ & $\frac{14.34}{1.357}$ & $\frac{17.48}{2.905}$ & $\frac{13.01}{1.651}$ & $\frac{21.90}{3.070}$ & $\frac{10.40}{0.747}$ & $\frac{13.87}{1.816}$ & $\frac{11.21}{1.125}$ \\
\hline 蓝藻门 & $\frac{10.62}{0.053}$ & $\frac{6.37}{0.045}$ & $\frac{16.99}{0.120}$ & $\frac{20.97}{0.200}$ & $\frac{22.21}{0.179}$ & $\frac{115.93}{1.186}$ & $\frac{9.07}{0.15 \overline{0}}$ & $\frac{105.40}{0.64 !}$ & $\frac{14.7 \%}{3.16 !}$ & $\frac{62}{0 .} \cdot \frac{17}{5 i 8}$ \\
\hline 复慕门 & $\frac{6.90}{1.150}$ & $\frac{4.43}{0.773}$ & $\frac{3.72}{0.930}$ & $\frac{2.66}{0.664}$ & $\frac{3.27}{1.298}$ & $\frac{5.04}{1.062}$ & $\frac{2.50}{0.47 i}$ & $\frac{3.16}{0.959}$ & $\frac{4.05}{563}$ & $\frac{3.97}{0.865}$ \\
\hline 棵暴门 & $\frac{4.96}{0.466}$ & $\frac{6.19}{0.366}$ & $\frac{2.12}{0.120}$ & $\frac{3.19}{0.299}$ & $\frac{\text { c. } .28}{0.543}$ & $\frac{10.09}{0.7}$ & $\frac{5.42}{0.523}$ & $\frac{4.56}{0.377}$ & $\frac{4.95}{0.413}$ & $\frac{6.01}{0.444}$ \\
\hline 甲萧门 & $\frac{0.0}{0.0}$ & $\frac{n}{0.0}$ & $\frac{2.1 \%}{3.3 .6}$ & $\frac{1.06}{0.672}$ & $\frac{0.58}{0.298}$ & $\frac{0.84}{0.336}$ & $\frac{0.0}{0.0}$ & $\frac{0.13}{0.0}$ & $\frac{0.68}{0.411}$ & $\frac{0.55}{0.0252}$ \\
\hline 金畹? & $\frac{0.71}{0.045}$ & $\frac{0 . \mathrm{c}}{0.0}$ & $\frac{0.0}{0.0}$ & $\frac{2.66}{0.170}$ & $\frac{0.0}{0.0}$ & $\frac{0.0}{0.0}$ & $\frac{0.0}{0.0}$ & $\frac{0.0}{0.0}$ & $\frac{0.18}{0.011}$ & $\frac{0.67}{0.043}$ \\
\hline 总 计 & $\frac{73.28}{3.689}$ & $\frac{69.56}{7.738}$ & $\frac{75.40}{4.828}$ & $\frac{91.61}{8.931}$ & $\frac{108.98}{8.974}$ & $\frac{203.28}{10.602}$ & $\frac{83.32}{7.312}$ & $\frac{189.78}{7.076}$ & $\frac{85.26}{6.202}$ & $\frac{138.56}{8.589}$ \\
\hline
\end{tabular}

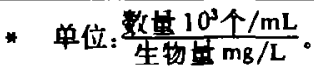
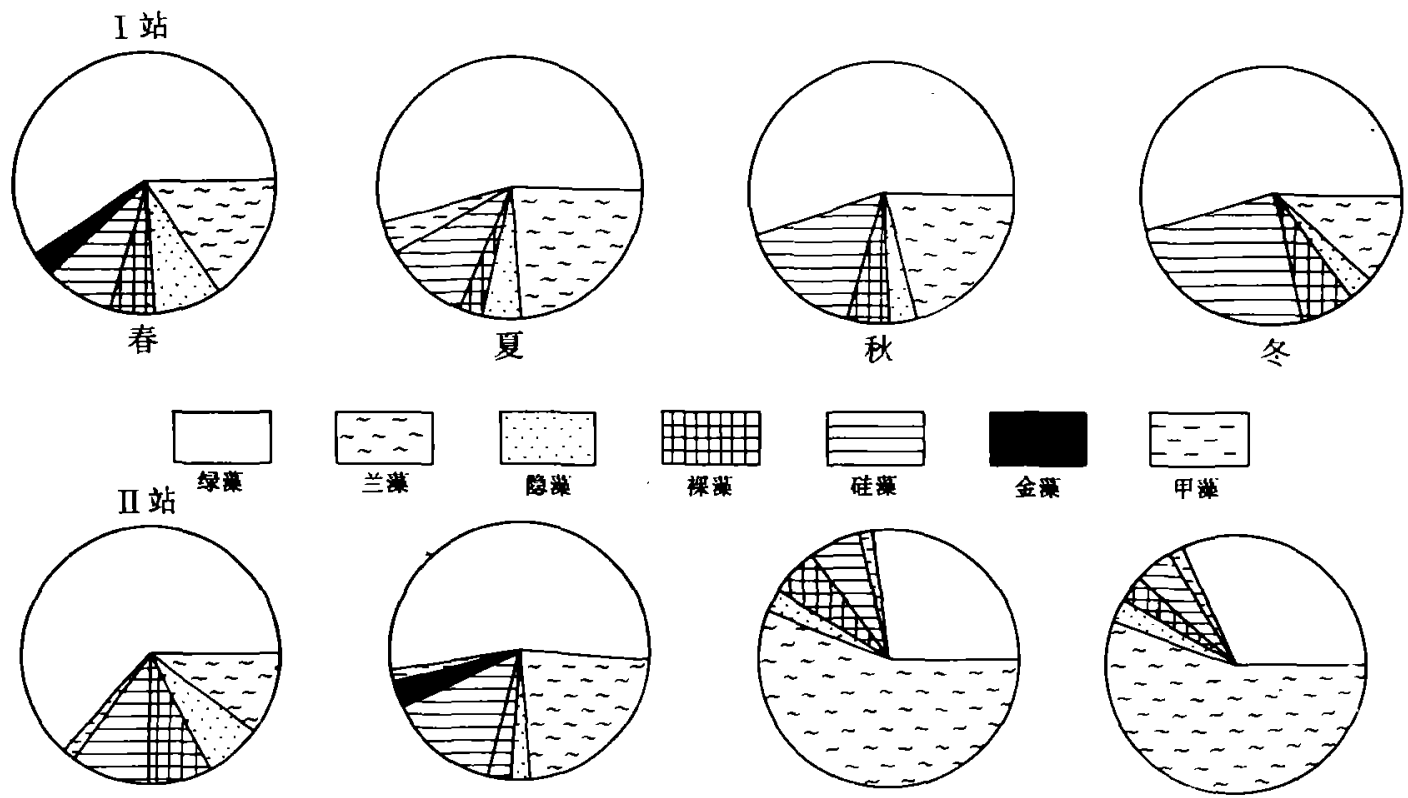

图 3 后湖浮斿植物种类组成(\%)的秄节变化

Fig. 3 Scasonal changes of phytoplankion specics (\%) in Houbu Lake 
总数的 $57.0 \%$ 和 $55.5 \%$, 其主要种类为 Oscillatoria acu lissima。

2. 2.2 生物立变动从图 4 中可以看出, 后湖浮游植物生物量相对百分数的季节变动:I 站、II 站全年均以绿藻门为最多，I 站波动在 $33.1 \%-43.7 \%$; I 站波动在 $53.2 \%-$

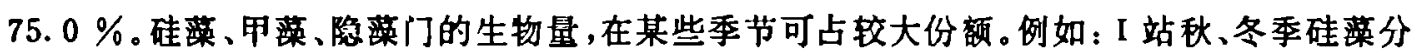
别占 $32.4 \%$ 和 $42.0 \%$; 藻夏季占 $27.8 \%$; 隐落春季占 $31.2 \%$ 。蓝㩰数量虽大,因个体小其 生物量占藻类总量的百行数不高。I、I 站全年变幅仅为 $0.5 \%-11.2 \%$ 。I、I 站浮游植 物年平均数量分别为 85250 和 138560 个 $/ \mathrm{mL}$, I 站约为 I 站的 1.6 倍; I 、I 站浮游植物年 平均生物量分别为 6.20 和 $8.59 \mathrm{mg} / \mathrm{L}$, I 站约为 I 站的 1.4 倍。
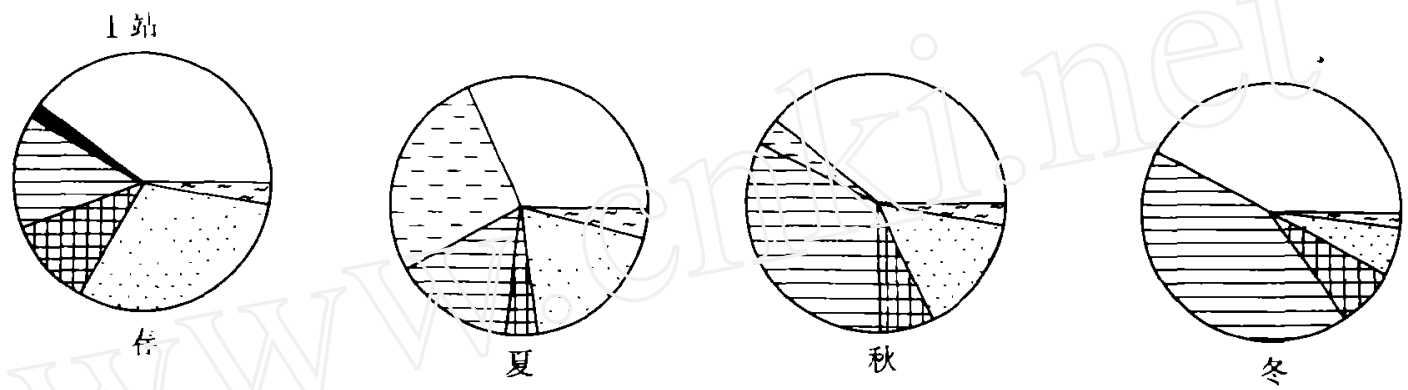

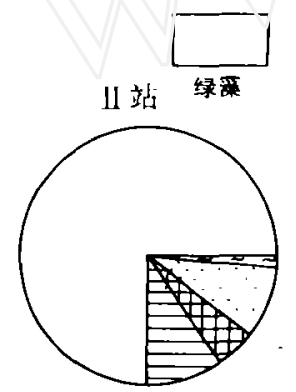

春
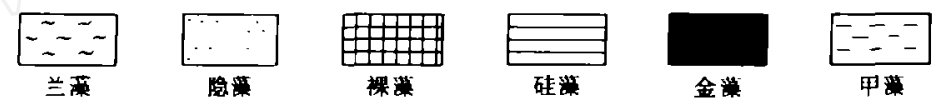

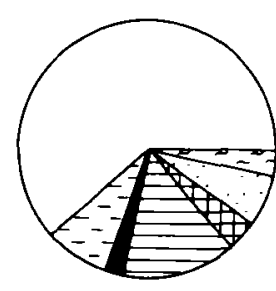

夏

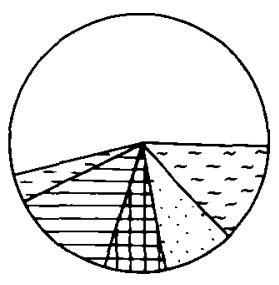

秋

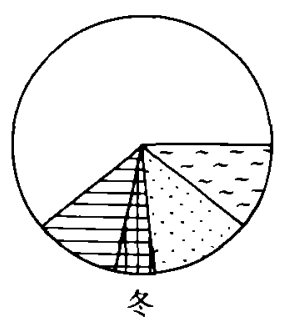

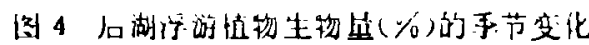

Fig. 4 Scasonal changes of phytoplankton biomass (\%) in Houhu Lake

I 站浮游植物数量与生物量较低的主要原因在于该站所处湖区水生高等植物茂盛, 要 盖面约占该湖区的 $65 \%-75 \%$, 其生物望约高达 $1323.6 \mu \mathrm{g} / \mathrm{m}^{2}$, 与浮游植物在光和营养盐 的竞争,导致㩰类生物量、生产力的抑制。1 站切相反,水草较少,故浮游植物生长良好。

I、I 站浮游植物数量和生物量变化趋势 (表 2) 相似。秋季浮游植物密度和生物量均朋 显高于其他季节, 冬季、夏季、春季低次较低。该湖浮游植物群落季节变动格局与武汉东湖一 水果湖区, 部郑湖、汤林湖区 60 年代浮游植物群落季节变动基本相似。而浮游植物密度、生 物量水平和季节变动规律与 70 年代初相近。

\section{3 浮游植物叶绿案含量的季节变动}

图 5 为后湖浮游植物叶绿素 $\mathrm{a}$ 和脱镁叶绿素 $\mathrm{a}$ 年季节变动曲线。I 站全年变幅分别为 $0.33-9.84 \mu \mathrm{g} / \mathrm{L}$ 和 $0.0-3.28 \mu \mathrm{g} / \mathrm{L}$ 。I 站为 $2.05-10.62 \mu \mathrm{g} / \mathrm{L}$ 和 $0.21-3.20 \mu \mathrm{g} / \mathrm{L}$ 。 


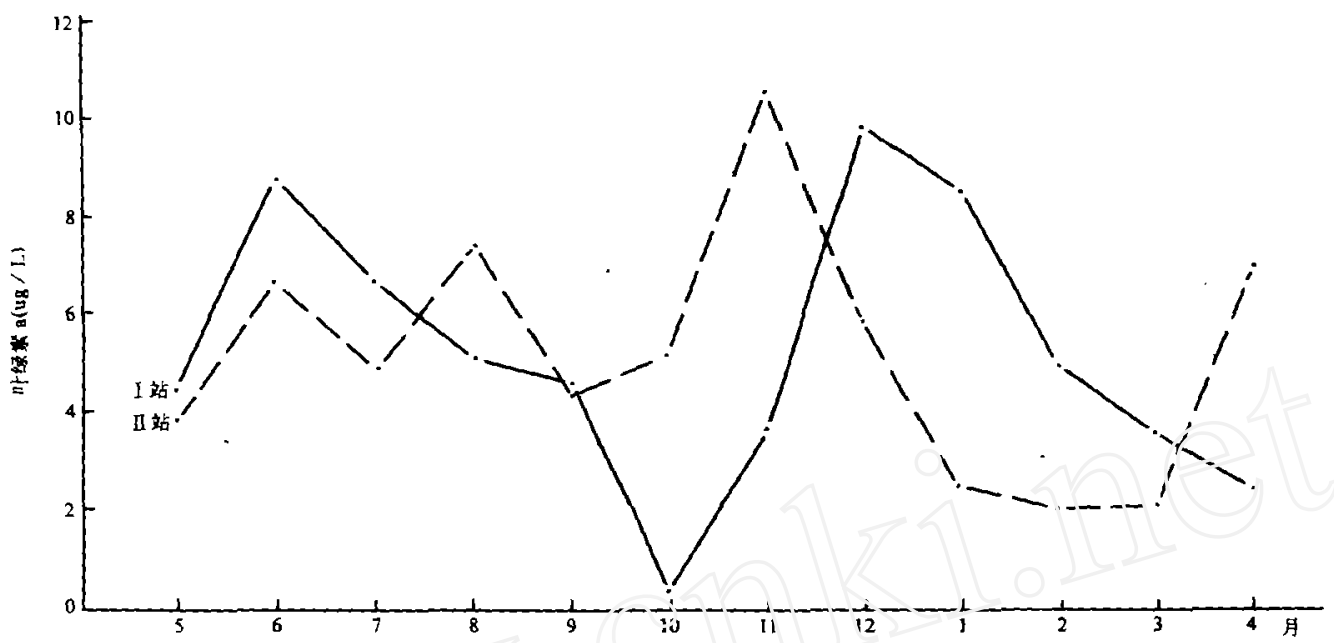

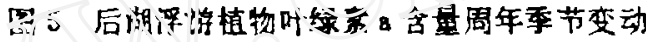

r.g. 5 Montily variuition of cblorphyll-a of phytoplankton in Houbu Lake

后湖澈㥀物叶绿 a 含量的季节分布, I 站夏、冬两季较高,分别为 $6.83 \mu 8 / \mathrm{L}$ 和 $7.77 \mu \mathrm{g} / \mathrm{L}$ ，春、秋两季较低,你别为 $3.50 \mu \mathrm{g} / \mathrm{L}$ 和 $2.83 \mu \mathrm{g} / \mathrm{L} ; 1$ 站略有不同,以夏、秋两季较 高,份别为 $6.34 \mu \mathrm{g} / \mathrm{L}$ 和 $6.68 \mu \mathrm{g} / \mathrm{L}$, 春、冬两季较低, 你别为 $4.52 \mu \mathrm{g} / \mathrm{L}$ 和 $2.10 \mu \mathrm{g} / \mathrm{L}$ 。

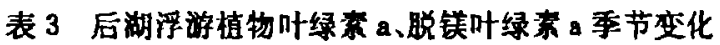

单位: $\mu \mathrm{B} / \mathrm{L}$

Tab. 3 Seasonal changes of chloropb ll-a and chlorophyll-a of phytoplankton in Houbu Lake

\begin{tabular}{|c|c|c|c|c|}
\hline \multirow{2}{*}{ 季节 } & \multicolumn{2}{|c|}{ 叶绿亲 } & \multicolumn{2}{|c|}{ 眹镁叶绿萧 a } \\
\hline & 1 站 & I站 & I站 & I站 \\
\hline 春(3-5 月) & 3. 50 & 4.52 & 1. 60 & 1.68 \\
\hline$E(6-8$ 月 $)$ & 6.83 & 6.34 & 2. 40 & 2.31 \\
\hline 秋(9-11月) & 2.83 & 6.68 & 2.07 & 2.10 \\
\hline 冬 (12-2月) & 7.77 & 2. 10 & 0.31 & 0.59 \\
\hline 坞值 & 5.23 & 4.91 & 1.60 & 1.67 \\
\hline 标雄差 & 2.43 & 2.09 & 0.92 & 0.77 \\
\hline
\end{tabular}

从表 3 可以看出，I，I站叶绿素 a 含量之均数或标准差,差异不大。可以认为，I，I站 叶绿素含量差异不显著。

\section{4 浮游植物初级生产量的季节变动}

后湖浮游植物水柱日产量全年变化在 $0.31-6.33 \mathrm{~g} \mathrm{O}_{2} / \mathrm{m}^{2} \mathrm{~d}$ 之问(图 6)。全湖植物年 总产量为 $3176.9 \mathrm{t} \mathrm{O}^{2}$ 。全年以夏季的生产量最离。以 I 站为例，夏季约占毛产量的 $32.1 \%$ ； 秋季其次，约占年总毛产量的 $24.95 \%$; 春季和冬季份别占全年总毛产量的 $11.80 \%$ 和 $10.50 \%$ 。游植物初级生产力的垂直分布和季节变动与光强、水温、水体营养元素有关。从 


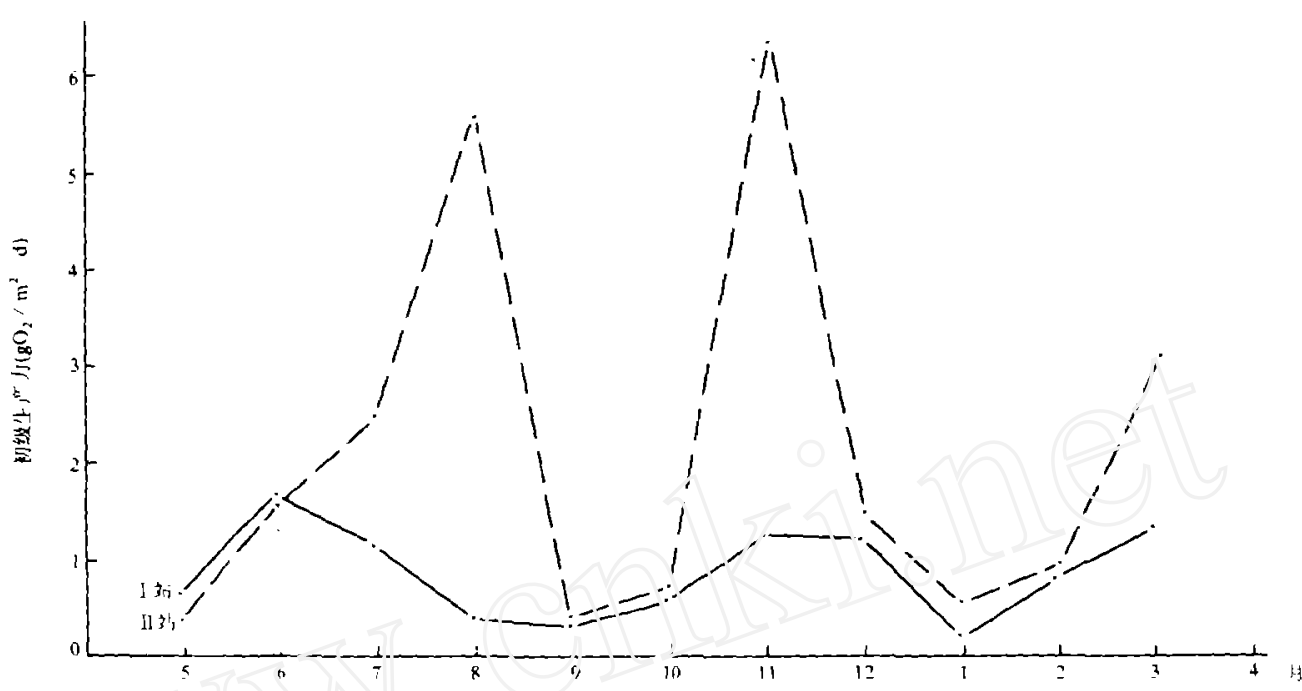

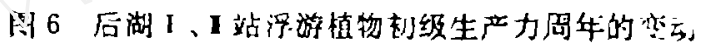

Fig. 6 Monthly variatiun of primary productivity of phyt nlankion at statiurts I \& I, Huubu Lake
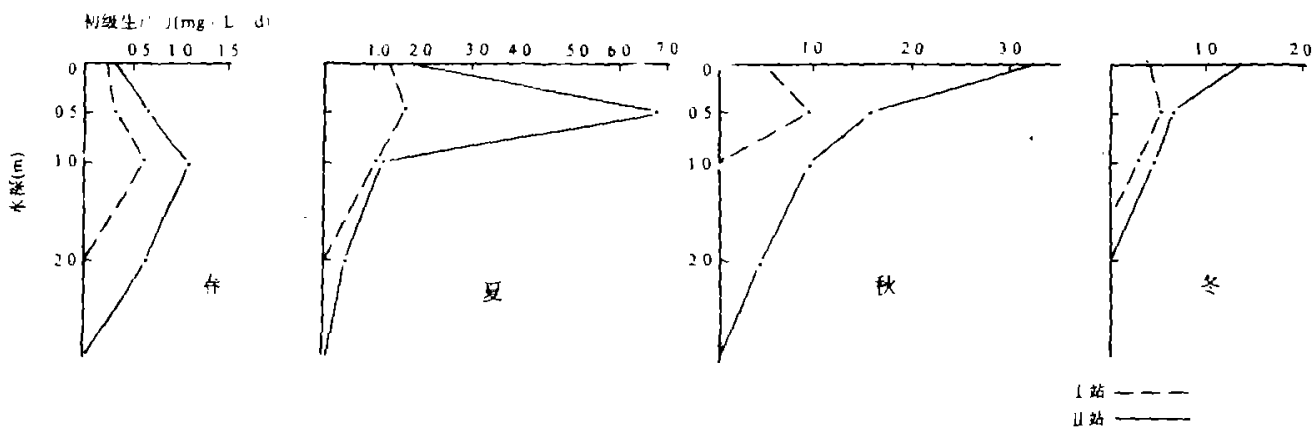

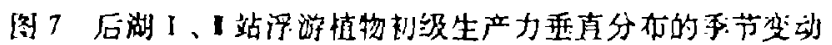

Tab. 7 Scasonal changes of vertical distribution of primary productivity for phytoplankton at stations I \& I

图 7 中看出, 最高生产量常出现在水表或 $0.5 \mathrm{~m}$ 或 $1.0 \mathrm{~m}$ 深处。晴天表层光强过大,出现光 抑制, 最高生产量常出现在 $0.5 \mathrm{~m}$ 或 $1.0 \mathrm{~m}$ 处, 最高生产层以下, 各水层则随着水深的增 加, 光照强度的减抲生产量逐渐降低。I 站最高生产层各季节均在 $0.5-1.0 \mathrm{~m}$ 。夏、秋、冬三 季节 $0.0-0.5 \mathrm{~m}$ 水层的毛产量分别占其水柱毛产量的 $52.1 \% 、 60.7 \%$ 和 $50.0 \%$, I 站与 I 站相同, 在这三个季节 $0.0-0.5 \mathrm{~m}$ 水层的毛产照分别占其毛产望 $43.4 \%, 47.3 \%$ 和 $50.0 \%$ 。

水柱毛产量无论 I 站或 I 站均以夏季最高。I 站、I 站分别为 $1.07 \mathrm{~g} \mathrm{O} \mathrm{O}_{2} / \mathrm{m}^{2} \mathrm{~d}$ 和 $4.79 \mathrm{~g} \mathrm{O}_{2} / \mathrm{m}^{2} \mathrm{~d}$ 。各占其水柱年产量的 $33.86 \%$ 和 $31.63 \%$ 。再次是春季、冬季最低(表 4)。 
表 4 后湖汿游植物初级生产力・

Tab. 4 Primary productivty of phytoplankton in Houbu Lake

\begin{tabular}{c|c|c|c|c|c}
\hline 站 & 春(3-5 月) & 豆 6-8 月) & 秋(9-11月) & 冬(12-2 月) & 总 计 \\
\hline I & $\frac{0.72}{22.78}$ & $\frac{1.07}{33.86}$ & $\frac{0.71}{22.47}$ & $\frac{0.66}{20.89}$ & $\frac{3.16}{100}$ \\
\hline$I$ & $\frac{1.75}{14.88}$ & $\frac{4.79}{40.73}$ & $\frac{3.72}{31.63}$ & $\frac{1.50}{12.76}$ & $\frac{11.76}{100}$ \\
\hline
\end{tabular}

* 单位: $\frac{\mathrm{g} \mathrm{O} / \mathrm{m}^{2} \mathrm{~d}}{\%}$ 。

\section{5 后湖浮游植物现状及其合理开发利用途径}

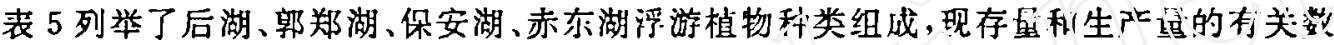

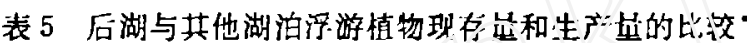

Tab. 5 Standing crops and productions of phytoplanktor: in Houth: Lake and other lakes

\begin{tabular}{|c|c|c|c|c|c|c|c|c|}
\hline \multirow{2}{*}{ 湖泊 } & \multirow{2}{*}{ 年份 } & \multirow{2}{*}{ 种 类 } & \multirow{2}{*}{ 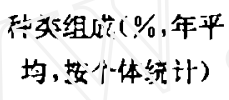 } & \multicolumn{2}{|c|}{ 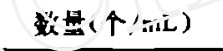 } & \multirow{2}{*}{$\begin{array}{l}\text { 季节变动 } \\
\text { 曲线特征 }\end{array}$} & \multirow{2}{*}{$\begin{array}{l}\text { 初级生产量 } \\
\left(\mathrm{g} \mathrm{O}_{2} / \mathrm{m}^{2} \mathrm{~d}\right)\end{array}$} & \multirow{2}{*}{$\begin{array}{l}\text { 营养 } \\
\text { 类型 }\end{array}$} \\
\hline & & & & 年平均 & 变 幅 & & & \\
\hline \multirow{3}{*}{ 东 } & $\begin{array}{c}19=6 \\
1 \\
1957\end{array}$ & 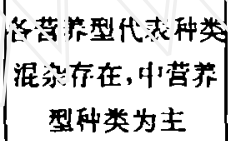 & $\begin{array}{c}\text { 甲㭉 ( } 40 \% \text { 以上) } \\
\text { 和硅蓝( } 20 \% \\
\text { 右)为主 }\end{array}$ & $10^{2}-10^{3}$ & $\begin{array}{l}50- \\
1000\end{array}$ & 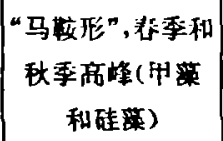 & - & 中一亩 \\
\hline & $\begin{array}{c}1962 \\
1 \\
1963\end{array}$ & 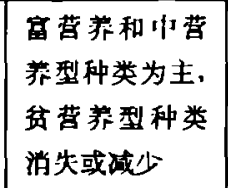 & $\begin{array}{l}\text { 绿 }(25 \%- \\
40 \%) \text { 和 蓝 } \\
(25 \%-30 \% \text { 左 } \\
\text { 右)为主 }\end{array}$ & $10^{3}$ 左右 & $\begin{array}{l}200- \\
2000\end{array}$ & 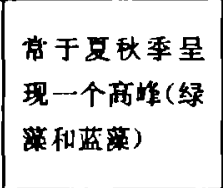 & $4.5-6.5$ & 富 \\
\hline & $\begin{array}{c}1973 \\
1 \\
1977\end{array}$ & $\begin{array}{l}\text { 富营养种类为 } \\
\text { 主 }\end{array}$ & $\begin{array}{l}\text { (30\%以上) } \\
\text { 和蓝 }(30 \% \text { 左 } \\
\text { 右)为主 }\end{array}$ & $10^{3}$ 以上 & $\begin{array}{l}500- \\
5000\end{array}$ & 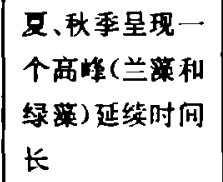 & $5.5-7.5$ & 曹 \\
\hline $\begin{array}{l}\text { 后 } \\
\text { 湖 }\end{array}$ & $\begin{array}{c}1990 \\
1 \\
1991\end{array}$ & 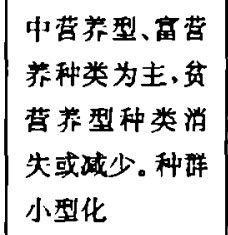 & $\begin{array}{l}\text { 绿藻 }(43.0 \%) \text { 和 } \\
\text { 蓝 }(26.0 \%) \text { 为 } \\
\text { 主 }\end{array}$ & $10^{3}$ 以上 & $\begin{array}{l}200- \\
2000\end{array}$ & $\begin{array}{l}\text { 秋、冬呈现一个 } \\
\text { 高峰(绿落和蓝 } \\
\text { 薄) }\end{array}$ & $0.3-6.3$ & 中-富 \\
\hline $\begin{array}{l}\text { 保 } \\
\text { 安 } \\
\text { 湖 }\end{array}$ & $\begin{array}{c}1986 \\
1 \\
1987\end{array}$ & $\begin{array}{l}\text { 营养型种类混 } \\
\text { 杂存在,中营养 } \\
\text { 型种类富营养 } \\
\text { 型种类为主 }\end{array}$ & $\begin{array}{l}\text { 隐藻 }(40 \%) \text { 和硅 } \\
\text { 㶾(30\%)为主 }\end{array}$ & $10^{3}$ & $\begin{array}{l}50- \\
1000\end{array}$ & $\begin{array}{l}\text { 耳、秋季呈现一 } \\
\text { 个高湈(隐和 } \\
\text { 硅藥) }\end{array}$ & $0.2-3.0$ & 贫-中 \\
\hline $\begin{array}{l}\text { 赤 } \\
\text { 东 } \\
\text { 湖 }\end{array}$ & $\begin{array}{l}1984 、 \\
1986\end{array}$ & $\begin{array}{l}\text { 富苦苑种类为 } \\
\text { 主 }\end{array}$ & $\begin{array}{l}\text { 蓝蕅 }(64 \%) \text { 和隐 } \\
\text { 蕗 }(20 \%) \text { 为主 }\end{array}$ & $10^{3}$ 以上 & $\begin{array}{l}500- \\
5000\end{array}$ & 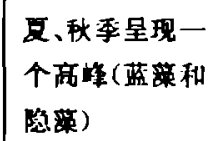 & 4. $7-5.7$ & 富 \\
\hline
\end{tabular}

* 东湖、保安湖和赤东湖有关资料来源于参考文献[3]、[4]、[5]。 
据。从中可以看出如今的后湖, 就其琈游植物种类、数量米说, 与郭郑湖 1962-1963 年相当, 即以绿滺、蓝为主, 游植物数量在 200-2000个 $/ \mathrm{mL}$ 左右。又根据 Winherg 提出的湖泊 分型标准, 最高水柱日产量达到 $2.5-7.5 \mathrm{~g} \mathrm{O}_{2} / \mathrm{m}^{2} \mathrm{~d}$ 时, 即属富营养型湖泊。后湖浮游植物 最高水柱日产量已达到 $6.33 \mathrm{~g} \mathrm{O}_{2} / \mathrm{m}^{2} \mathrm{~d}$, 故, 可以认为, 该湖已属富营养型湖泊。

长江中下游浅水湖泊是我国特有的园土资源。因此研究、开发和保护这类水体防止或延 缓水体富营养化,使之健康运转,持续利用是一项极待解决的问题。

后湖位于武汉市东郊,地理位置极为重要, 应把维护环境放在首位; 同时在兼顾环境的 前提下发展名、特、优水产和游钓业,使生态、环境、经济效应同步增长。

\title{
考文堿
}

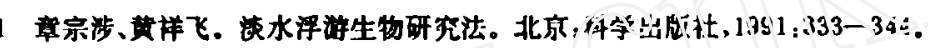

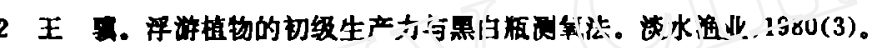

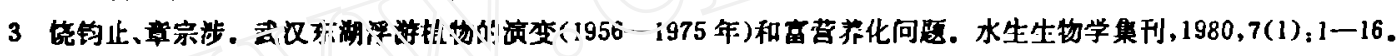

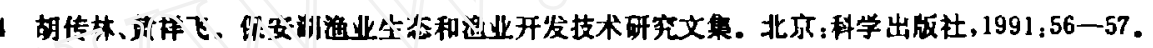

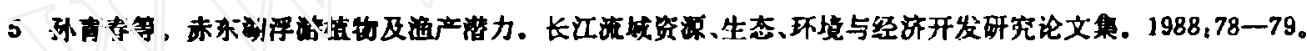

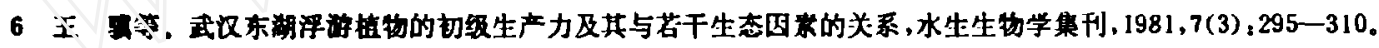

7 Hussaing S. U., Bacterial and algal ctlorophyll in low salt lakes in Vitoria, A ustralia, IV ater Resporch, Pergamon Press. $1972,8: 1361-1365$.

8 Hustedt, F., Bacillariophyta, in pascher, Susswasserflora Von Mittclceuropas, Heft. X. No. 2 Auft, Jena, 1930.

\section{SEASONAL CHANGES OF STANDING CROP AND PRODUCTION OF PHYTOPLANKTON IN HOUHU LAKE, WUHAN}

\author{
Rong Kewen \\ (Institule of Hydrobiclogy, Chimese Acolemy of Scipaces, Wklian 430072)
}

\begin{abstract}
According to the annual variations (May 1990-April 1991) of species composition, standing crop and productions of phytoplankton in Houhu Lake, Wuhan, it is found that the dominant taxa are no other than Chloropgyta, Bacillatiophyta and Cyanophyta in the lake with their standing crop and production being highest in autumn and lowest in spring. On the basis of the ecology of phytoplankton community, some comprehensive evaluation on the trophic state of Houhu Lake is suggested.
\end{abstract}

- Key Words Phytoplankton, standing crop, production, Houhu Lake of Wahan, Donghu Lake of Wuhan 